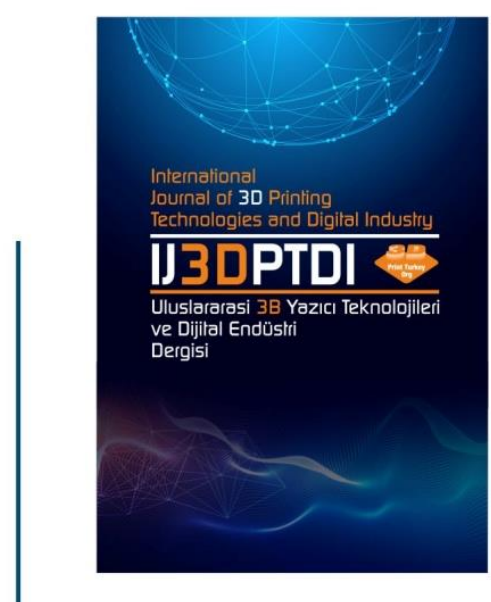

ULUSLARARASI 3B YAZICI TEKNOLOJILERI

VE DIJITAL ENDÜSTRI DERGISI

INTERNATIONAL JOURNAL QF 30 PRINTING TECHNOLOGIES AND DIGITAL INDUSTRY

ISSN:2602-3350 [Online]

URL: https://dergipark.org.tr/ij3dptdi

\title{
DESIGNING AND 3D PRINTED PLA BASED IMPLANT USED IN TREATMENT FOR UNILATERAL VOCAL CORD PARALYSIS
}

Yazarlar (Authors): Fatih Ciftci ${ }^{*}$ *, Sümeyra Ayan, $\mathbb{D}$, Cem Bulent Ustundag

Bu makaleye şu şekilde atıfta bulunabilirsiniz (To cite to this article): Ciftci F., Ayan S., Ustundag C.B. "Designing And 3d Printed Pla Based Implant Used In Treatment For Unilateral Vocal Cord Paralysis" Int. J. of 3D Printing Tech. Dig. Ind., 5(3): 416-425, (2021). 


\title{
DESIGNING AND 3D PRINTED PLA BASED IMPLANT USED IN TREATMENT FOR UNILATERAL VOCAL CORD PARALYSIS
}

\author{
Fatih Ciftci $^{\mathrm{a}, \mathrm{b}}$ (iD)*, Sumeyra Ayan ${ }^{\mathrm{c}, \mathrm{d}}$ iD, Cem Bulent Ustundag ${ }^{\mathrm{c}}$ \\ ${ }^{a}$ Depatment of Biomedical Engineering, Fatih Sultan Mehmet Vakif University, 34445 Beyoğlu, Istanbul, Turkey \\ ${ }^{\text {b}}$ Technology Transfer Office, Fatih Sultan Mehmet Vakif University, 34015 Zeytinburnu, Istanbul, Turkey \\ ${ }^{c}$ Department of Bioengineering, Yildiz Technical University, 34220 Esenler, Istanbul, Turkey \\ ${ }^{\mathrm{d}}$ Materials Institute, Marmara Research Center, TUBITAK, 41470 Gebze, Turkey \\ *Correponding Author: faciftcii@gmail.com
}

(Received: 01.10.2021; Revised: 19.10.2021; Accepted: 01.11.2021)

\begin{abstract}
This study aims to develop and demonstrate a new method of creating polymeric vocal cord (VC) models via 3D printing to reduce model production time, increase sound efficiency, and lay the groundwork for future models using more realistic geometric and functional biomaterials. For this purpose, it is to produce a poly (lactic acid) (PLA) based VC implant using a 3D printer as a special design according to the patient's vocal structure. In this study, VC 3D PLA implant (VC3DPLAI), VC stretch piece (measured $=35 \mathrm{~mm}$ length), fixed to thyroid cartilage VC (cartilage length $=12 \mathrm{~mm}$ ) and titanium (Ti64) springs pieces are expected to be produced as a patient-specific implant It is composed of three different biomechanical designs. When you compare this implant with other biomaterials, the VC3DPLAI provides personal convenience compared to complex models and allows unlimited time-cost competition.
\end{abstract}

Keywords: 3D printer, Biomaterials, Implants, Poly (lactic-acid), Thyroplasty, Vocal cord paralysis.

\section{INTRODUCTION}

Vocal cord (VC) is located in the larynx, right and left. Vocal cord paralysis (VCP) is a voice event that occurs when vocal cord superior (VCS) and vocal cord inferior (VCI) laryngeal nerves do not touch their vocal tracts in the glottic space during phonation [1]-[3]. VCP is generally evaluated in two main groups, one and two sides. In unilateral paralysis, as the affected VC does not reach the midline sufficiently, more space is left between the two cords and the voice becomes quiet. If bilateral paralysis is not enough to open the cords in the middle; although the sound is good, there is not enough air passage, so shortness of breath occurs. Treatment of both conditions is different. The purpose of the one-sided paralysis is to correct voice shortness while the bilateral goal is to correct breath shortness. Medialization technique, which was first applied by Isshiki, is the laryngeal frame surgeon [3]-[7]. In Ishiki's Type-I thyroplasty method, the thyroid cartilage opened a window in the lateral lamina, from which it placed a cylindrical block by medializing the paralytic cavity. In this technique, paralytic side of paralytics textures are brought to the middle line and contacted with the opposite cord [8]-[13]. The medialization laryngoplasty technique applied in vocal cord paralysis is better in terms of sound quality than injected laryngoplasty. Implants applied in Type-I surgery do not change because they are biologically and chemically static with preserved dimensions over time [14], [15]. The permanent vocal mucosa structure in the paraglottic space may cause fibrosis but may be removed more easily than the injection material. Attempts to implant prostheses by laryngoplasty to medialize immobile vocal-preserved and functional prosthesis designs have been increasing day by day [15]-[18]. Many biomaterials are used as VC implant materials such as silicon construction, titanium construction and bioceramic construction materials (Table 1). 
Table 1. List of biomaterials are used as VC implant materials

\begin{tabular}{|c|c|c|}
\hline Material & Advantage & Disadvantage \\
\hline Silicon [19], [20] & $\begin{array}{l}\text { Very low financial cost, } \\
\text { Inert material, } \\
\text { Easy to shape and adapt to the individual } \\
\text { situation }\end{array}$ & To not fix to the thyroid ala \\
\hline Titanium [21]-[23] & $\begin{array}{l}\text { Relatively safe implant material with excellent } \\
\text { biocompatibility, } \\
\text { Easy to shape and adapt to the individual } \\
\text { situation, } \\
\text { The design of the implant ensures optimal } \\
\text { fixation and stabilization, } \\
\text { The implantation is simple and time-saving }\end{array}$ & $\begin{array}{l}\text { Graft rejection and some } \\
\text { potential complications }\end{array}$ \\
\hline $\begin{array}{l}\text { Hydroxyapatite (HA) [23], } \\
{[26]}\end{array}$ & $\begin{array}{l}\text { Rapid determination of correct size and } \\
\text { position, } \\
\text { Calcium hydroxyapatite is a FDA approved } \\
\text { material, } \\
\text { Improved implant stabilization, } \\
\text { To minimize tissue reactivity, } \\
\text { Locking shims for stabilization }\end{array}$ & $\begin{array}{l}\text { Graft rejection and some } \\
\text { potential complications }\end{array}$ \\
\hline $\begin{array}{l}\text { Lyophilized glutaraldehyde- } \\
\text { preserved bovine pericardium } \\
\text { (LGPBP) [27], [28] }\end{array}$ & $\begin{array}{l}\text { Easy to insert/remove from the microfenestra, } \\
\text { fold, cut, and give shape, } \\
\text { Great flexibility }\end{array}$ & Less memory \\
\hline $\begin{array}{l}\text { Polytetrafluoroethylene } \\
\text { (PTFE) [27], [29], [30] }\end{array}$ & Great memory & $\begin{array}{l}\text { Difficult to cut and give shape, } \\
\text { Less flexibility }\end{array}$ \\
\hline $\begin{array}{l}\text { Polyethylene terephthalate } \\
\text { [31]-[33] (PET) }\end{array}$ & Great memory & $\begin{array}{l}\text { Difficult to cut and give shape, } \\
\text { Less flexibility, }\end{array}$ \\
\hline Teflon felt (TF) [34], [35] & Great memory & $\begin{array}{l}\text { Difficult to fold, cut, give } \\
\text { shape, insert/remove from the } \\
\text { microfenestra, } \\
\text { The requirement for patient } \\
\text { cooperation, } \\
\text { Less flexibility }\end{array}$ \\
\hline
\end{tabular}

This study has discussed the advantage of other PLA-based vocal cord implant models. PLA is a well-known established aliphatic polymer. Its elastic modulus is between 1.5-2.7 GPa and glass transition temperature is around $60^{\circ} \mathrm{C}$. Thus, PLA offers great mechanical properties, provides easy blending with many plasticizers to achieve desired rigidity [36]-[38]. In addition, stabilization properties of printed structure are very favorable. Properties of PLA inks for solvent-cast printing of three-dimensional freeform microstructures [39]-[41]. It is semi-crystalline, biocompatible, and has found use in several medical applications like orthopedic implants, drug delivery systems, and bio-fabrication [38], [42]. The semi-crystalline morphology increases mechanical integrity. It is also a hydrophobic polymer, which provides a slow degradation time due to its tendency of non- 
interaction with water molecules [43]-[46]. Surface modification and tailoring mechanical properties are simpler than its alternatives [47]. Better biocompatibility can be achieved by surface modifications of PLA [48], [49]. Furthermore, surface coatings with inert materials and making cross-linked PLA with other polymers can increase degradation time and that makes PLA a splendid prosthetics material candidate [50][53]. In this study, it used with commercially available biomaterials, PLA filaments and VC model which are produced by 3D printer were discussed. How it works, its advantages and disadvantages compared to other similar ones are also discussed.

\section{MATERIAL AND METHOD}

Except springs all implant parts were printed with the Kupido 3D printer. PLA material is used in this device. This PLA filament was purchased from eSun PLA+ (4043D), of which the average diameter is $1.75 \mathrm{~mm} \pm$ $0.05 \mathrm{~mm}$. This FDM printing technology, the printing nozzles temperature was set in the range $190^{\circ}-205^{\circ}$. Other properties; heated aluminum table; $60^{\circ}$, nozzles size; $0.4 \mathrm{~mm}$, smooth, durable, print speed; $150 \%$ $\mathrm{mm} / \mathrm{sec}$.

Vocal design consists of three biomechanical designs and methods. Vocal tension piece, fixed to thyroid cartilage and springs that provide flexibility of these two pieces. The technical drawings were made with the Solidworks program. The reason why the thyroid cartilage part is open at both ends is that it creates a cartilage bridge and supports the vocal cord appearance of the vocal back part. The springs are adjusted by pushing and pulling with the cartilage part and provide the desired flexibility in the vocal back part. In this way, the lost sound function will be regained.

The implant prototype is shown in Figure 1 and Figure 3 as a PLA based 3D printed implant model designed and developed for VCP medialization type I surgery. VC3DPLAI model has been our main aim to restore the patient's voice function by adjusting patient's VC tension. Previously used biomaterials, while still providing a static structure to the patient vocal, were only able to serve as fold to the cords and could not produce a permanent and innovative solution to the lost sound aesthetic.

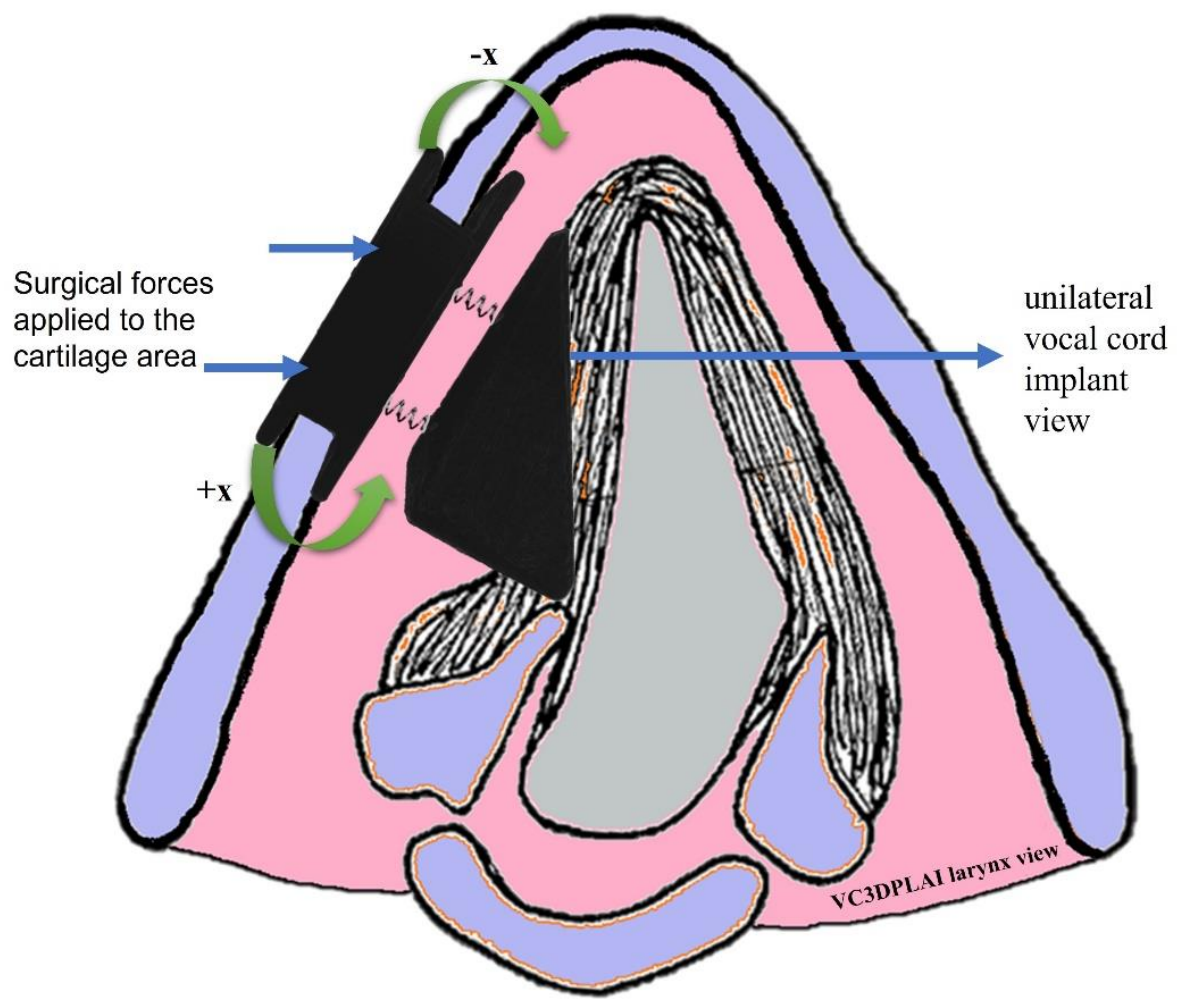

Figure 1. VC3DPLAI Larynx view 
VC3DPLAI's technical drawing and 3D printer material are shown in Figure 2 and Figure 4. In the technical study, VC3DPLAI is designed and manufactured according to the person, so the technical drawing data on it is calculated and modeled by taking the average values from the general literature data.

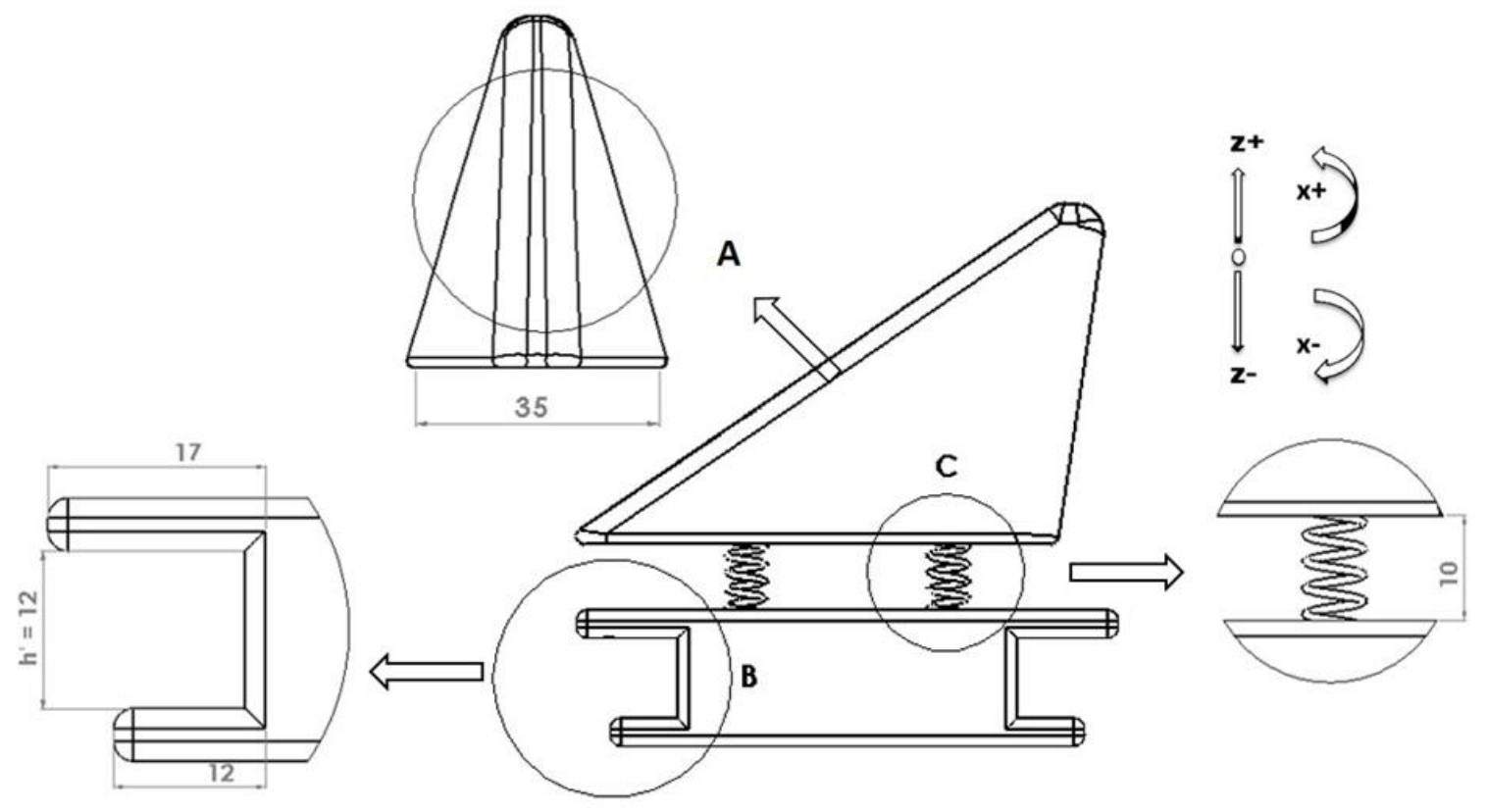

Figure 2. VC prototype technical drawing (This prototype was draw and designed with Solidworks program)

Implant model's work system;

A. VC stretch piece: unilateral VC region designed to create the VC print/back in the tissue region where the $\mathrm{VC}$ is formed. This part (with part $\mathrm{C}$ springs) provides back and forth stretch in the ${ }^{+} \mathrm{z}$ and ${ }^{ } \mathrm{z}$ directions at zero angle. Furthermore; this part makes an angle in the ${ }^{+} \mathrm{x} / \mathrm{x}$ directions (with part $\mathrm{C}$ springs). This system with, which brings the vocal to the medial position by making an angle, improves both the quality of the functional change of the degradation of the structure of the mucosa. This piece supporting the $\mathrm{VC}$ was measured in $\mathrm{T}=35 \mathrm{~mm}(\mathrm{~T}$; cover inferior medial surface) length. This cord piece has been given a depth (A; cover medial surface) so that the cord can and function without slipping and exuding. This depth varies according to male and female cord structure. The closer the spring distances (spring release, $10 \mathrm{~mm}$ ) are kept, the farther we can provide the flexibility of the spring.

B. Fixed to thyroid cartilage VC: this part is the lower part of the cartilage that stabilizes the cartilage. Muscle attached to cartilage length is $=12 \mathrm{~mm}$ ( $h$ ').

C. Titanium springs: these springs is Ti64 biomaterial that provides both a stabilized structure and a dynamic function for parts $\mathrm{A}$ and $\mathrm{B}$.

\section{RESULTS AND DISCUSSION}

Voice communication depends on symmetrical vibrations within the $\mathrm{VC}$ and is indispensable for various professions such as sales representative, teacher, and doctor. Unexpected dysphonia can force individuals to quit their jobs [54]. VCP is treated by MT 1 surgery. Many implants have been tried for this treatment in the past years. For instance, in the early days, thyroid cartilage was used by itself, and later years many implants such as polytetrafluoroethylene were used. The choice of implant depends mainly on surgical experience. There is no difference between existing implants in terms of surgical success and complications.

Thyroprotip ${ }^{\mathrm{TM}}$ titanium model (Strasbourg, France, Figure 3.a) [55] is adjustable implant model with porous structure. This model is the closest implant system to the original desired design. Adjustable bolt is available to increase or decrease sound aesthetics. The cord design, which will bring the paralyzed folded shears to the medial level, is in a pore structure. Injuries can be avoided by injecting antibiotics on the porous structure to 
prevent complications that may have occurred in wounded or ulcerated surgical injuries. However, system design will have negative implications for future granulomal development on implant model when both porosity and bolt structure are taken into consideration. Tissue formation will transform the whole system into a non-smoothing and convert it into a fully functional model with the fully rigid Montgomery silastic system. In addition, since tissue formation is excessive, it is difficult to remove the implant. TVFMI ${ }^{\mathrm{TM}}$ titanium model (Gerhard Friedrich M.D design, Figure 3.b) [56] is a static implant model. Like the clamp system, it compresses the paralyzed fold tissue at the medial level. The contribution of the titanium material to the sound quality is important. Dean and coworkers performed an adjustable laryngeal implant made of titanium developed for the treatment of unilateral VCP. Analysis of subjective responses confirmed marked development in normal laryngeal function, swallowing, and speech. According to their examination, the implant has many advantages containing: exact medialization, ease of secondary adjustment, and conservation of the mucosal wave [57].

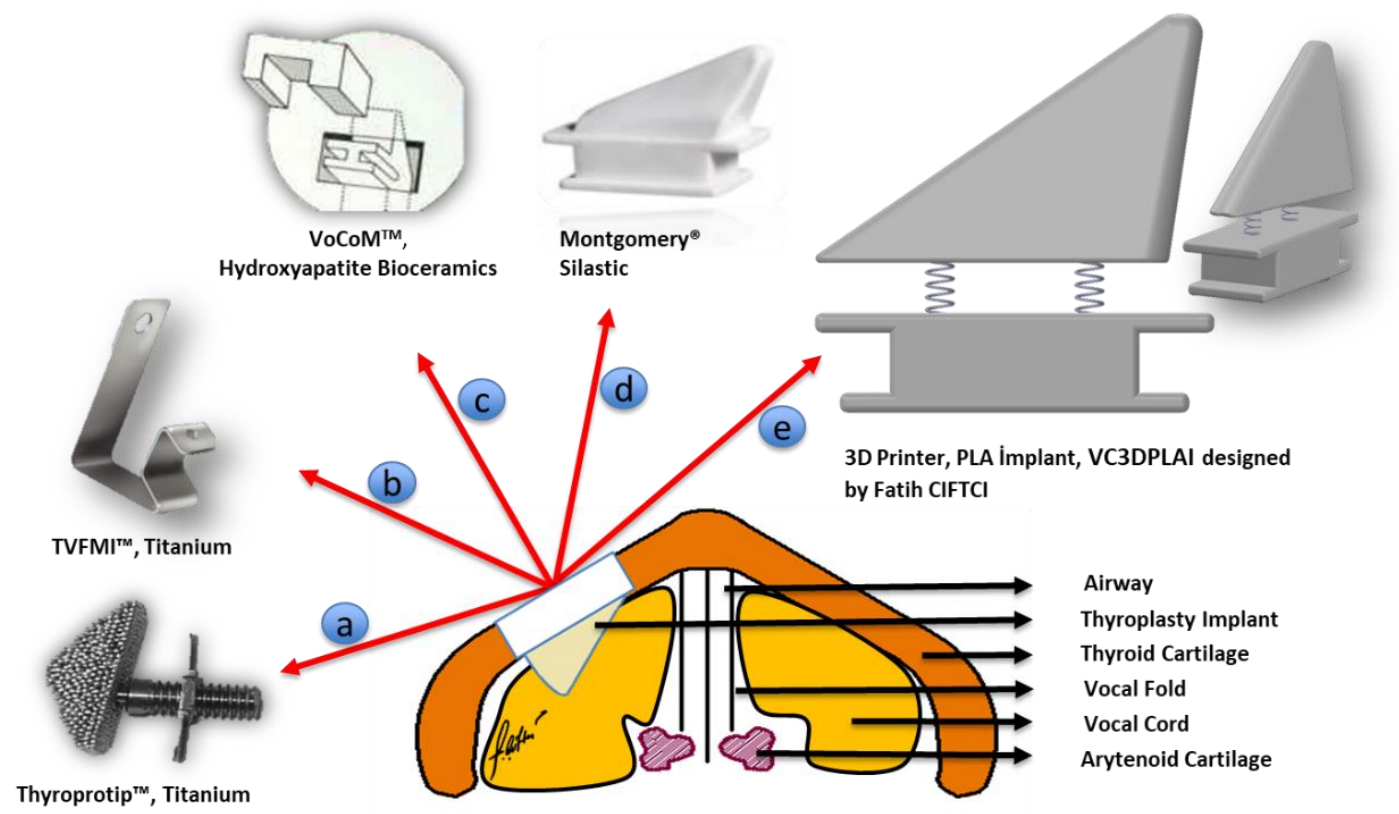

Figure 3. All biomaterial implants used and produced for VC medialization Type 1 surgery, a. Titanium, Thyroprotip ${ }^{\mathrm{TM}}$, manufactured by PROTOTIP, Strasbourg, France [55] b. TVFMITM Titanium Medialization Implant, Gerhard Friedrich M.D. (Graz, Austria) design [58] c. Hydroxyapatite Bioceramics VoCoM ${ }^{\mathrm{TM}}$, d. Montgomery ${ }^{\circledR}$ Silastic [59][60] e. 3D Printer manufactured with PLA as prototype, Istanbul, Turkey

$\mathrm{VoCOM}^{\mathrm{TM}}$ model (Figure 3.c) [61]-[63] is a hydroxyapatite bioceramically based VC implant material. The rigid structure, inert, the same mineral as the bone and the tooth, can be used for bringing the design model to the fore in terms of its chemical properties and its attachment properties. Moreover hydroxyapatite is useful in order to improve implant stabilization. Calcium hydroxylapatite is a kind of bio-ceramic that is approved by FDA in order to use as implant. However, graft rejection and some potential complications are limitations of using hydroxyapatite [62], [64]-[66].

The Montgomery ${ }^{\circledR}$ model (Figure 3.d) [67], [68] is injection molded implanted and used as a silicone material. It only provides a temporary solution to voice functions. There is no quality or enhancement function in the sound quality. Silicone is very cheap, inert material, and easy to shape and adapt to the individual situation. However, it is not fix to the thyroid ala [68].

VC3DPLAI model (Figure 3.e and prototype material Figure 4) we designed offers an alternative to the use and placement of nanocomposite and nanoparticle materials in the treatment of grafts present in vocal cord paralysis and in the treatment phase. This model, which can be adapted to the existing cartilage window, is more suitable for revision surgeries as it will reduce costs. Region B of the model (Figure 4) is designed to hold onto vocal cartilages and to prevent extrusion. The spring in zone 3 is Ti64 material, providing both 
stabilization and dynamic operation. Areas B and $\mathrm{C}$ are coated with hydroxyapatite to activate the surface to provide tissue formation at the fold. Part A is designed to bring the vocal fold to the medial level. The upper and lower points are cylindrical and thought to be non-damaging to tissue. The VC3DPLAI model will be custom designed, according to symphtom phases of fold paralysis, implant model can be designed and producteed as porous structures.

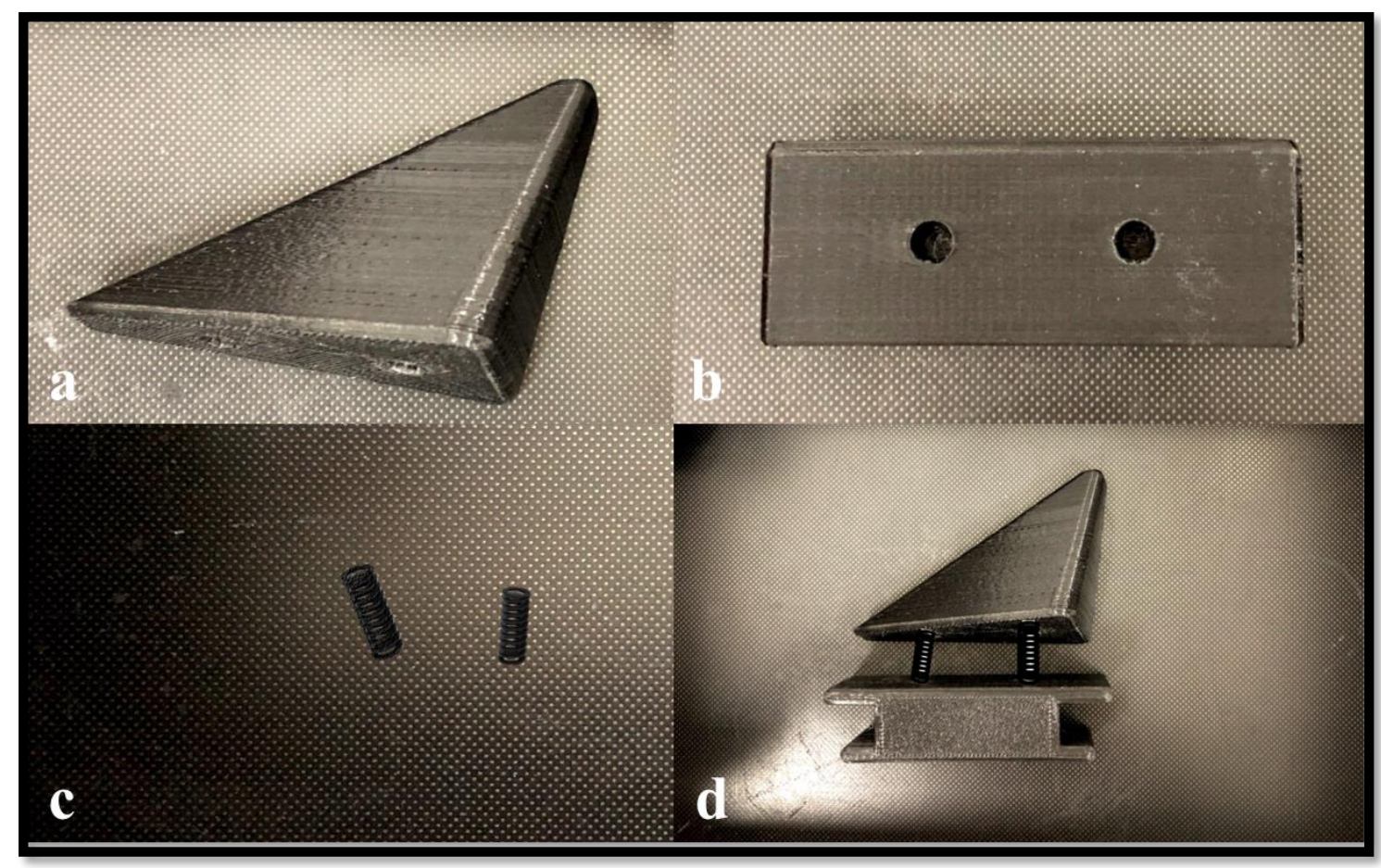

Figure 4. Manufactured VC3DPLAI prototype model materials, a. VC stretch piece b. fixed to thyroid cartilage VC c. titanium springs d. VC implant model

\section{CONCLUSION}

Recent studies, the VC implants being manufactured are produced as a uniform standard in the static structure. However, these standard dimensions do not correspond individually to the cord or fold structure, which is different anatomical structure for each person. This treatment does not contribute to sound aesthetics. In order to eliminate this problem, in this study, modeling of the unique VC implant using 3D printing technology was compared with other counterparts. Although the prefabricated products that are ready to be used in vocal implants to be manufactured are accepted as the gold standard due to their biocompatibility and superior mechanical properties, they are not able to provide aesthetic image adequately, they are inadequate as a result of implantation with distal angulation and placement and they cannot provide a voice function profile close to the ideal. As a result of that, old implants leave their place to 3D printed implants which can be customizable and ideally designed for each patient. It has been reported by many studies that there are many advantages of the patient specific implants in terms of both function and aesthetics over the prefabricated implants.

In this study, VC3DPLAI was designed and prototyped and custom mode design was discussed. This model, which is expected to be produced as a patient-specific implant by examining the morphologic structure of a UVCP patient, allows for an unlimited amount of time-cost competitiveness, considering personal suitability compared to complex models. The long-term success of the VC3DPLAI implant model, which is to be prepared with a person-specific basis, an important tool for solving prosthetic problems, is not yet known. However, the success of the VC3DPLAI implant is planned to be clarified in the future in line with possible clinical studies and reports. VCP treatments are an important issue for both the application as a surgical technique and the material mechanics and biocompatibility to be developed for this application. Although this 
approach, which stands as an innovative solution for Ear Nose and Throat surgery, seems scientifically innovative, it should be practically tried and developed by working with otolaryngologists.

\section{ACKNOWLEDGEMENT}

This work is supported by the Yildiz Technology Transfer Office with patent applications. Patent Application numbers: 2018/00167, 2017/21650, 2017/19741

\section{REFERENCES}

1. S. George and S. Suresh, "Vocal cord dysfunction: Analysis of 27 cases and updated review of pathophysiology \& management," International Archives of Otorhinolaryngology, Vol. 23, Issue 2, Pages 125-130, 2019.

2. M. Wenzel, "Gasping for a Diagnosis: Pediatric Vocal Cord Dysfunction,” J. Pediatr. Heal. Care, Vol. 33, Issue 1, Pages 5-13, 2019.

3. J. F. Val-Bernal, M. Martino, and M. Y. Longarela, "Cellular myxoma of the vocal cord: A case report and review of the literature,” Turk Patoloji Derg., Vol. 36, Issue 1, Pages 77-81, 2020.

4. S. Alicura Tokgöz et al., "Effects of phenytoin injection on vocal cord healing after mechanical trauma: An experimental study," Turkish J. Med. Sci., Vol. 49, Pages 1577-1581, 2019.

5. H. Zavala, B. B. Roby, A. Day, B. Bostrom, J. Sidman, and S. Chinnadurai, "Vincristine-induced vocal cord paresis and paralysis in children,” Int. J. Pediatr. Otorhinolaryngol., Vol. 123, Pages 1-4, 2019.

6. G. O. Dahle et al., "Vocal cord function during recurrent laryngeal nerve injury assessed by accelerometry and EMG," Laryngoscope, Vol. 130, Issue 4, Pages 1090-1096, 2020.

7. W. W. Montgomery, “Thyroplasty: A New Approach, Vol. 102, Issue 8,” Pages 571-579, 1993.

8. J. Saniasiaya, N. F. H. N. Hassan, and B. S. S. Singh, "Unilateral vocal cord palsy: A never-ending diagnostic dilemma," Pediatr. i Med. Rodz., Vol. 16, Issue 2, Pages 217-220, 2020.

9. M. K. Shah, B. Ghai, N. Bhatia, R. K. Verma, and N. K. Panda, "Comparison of transcutaneous laryngeal ultrasound with video laryngoscope for assessing the vocal cord mobility in patients undergoing thyroid surgery," Auris Nasus Larynx, Vol. 46, Issue 4, Pages 593-598, 2019.

10. L. P. Stoltz, M. L. Fajt, A. A. Petrov, and R. S. Traister, "Vocal Cord Dysfunction: A Review," Clin. Pulm. Med., Vol. 25, Issue 4, Pages 125-130, 2018.

11. X. G. Ni, J. Q. Zhu, Q. Q. Zhang, B. G. Zhang, and G. Q. Wang, "Diagnosis of vocal cord leukoplakia: The role of a novel narrow band imaging endoscopic classification,” Laryngoscope, Vol. 129, Issue 2, Pages 429-434, 2019.

12. M. Eddaoudi, S. Rostom, B. Amine, and R. Bahiri, "The involvement of vocal cords in rheumatoid arthritis: A clinical case," Pan Afr. Med. J., Vol. 34, Pages 102, 2019.

13. F. Bertone, E. Robiolio, and C. F. Gervasio, "Vocal cord ulcer following endotracheal intubation for mechanical ventilation in COVID-19 pneumonia: A case report from northern Italy," Am. J. Case Rep., Vol. 4, Pages 21, 2020.

14. J. Il Kim, D. H. Lee, and H. Kim, "Bilateral vocal cord paralysis during emergence from general anesthesia in a patient with Parkinson's disease,” Saudi J. Anaesth., Vol. 14, Issue 1, Pages 112-114, 2020.

15. Q. Duan et al., "Vocal cord paralysis following lithium button battery ingestion in children,” Eur. J. Pediatr., Vol. 180, Issue 4, Pages 1059-1066, 2021.

16. Y. Chiche et al., "Bilateral vocal cord paralysis after endoscopic placement of fully covered self-expandable metal stent for palliative treatment of malignant proximal esophageal obstruction: Two case reports," BMC Gastroenterol., Vol. 20, Pages 153, 2020. 
17. M. H. R. Raja, M. A. Javed, and A. B. S. Zubairi, "Sarcoidosis presenting as vocal cord palsy: an unusual presentation and literature review," Respirol. Case Reports, Vol. 9, Issue 2, 2021.

18. N. M. Dunn, R. K. Katial, and F. C. L. Hoyte, "Vocal cord dysfunction: a review,” Asthma Res. Pract., Vol. 1, Pages $9,2015$.

19. H. Iwatake, J. Iida, S. Minami, S. Sugano, T. Hoshikawa, and I. Takeyama, "Transcutaneous intracordal silicon injection for unilateral vocal cord paralysis,” Acta Oto-Laryngologica, Suppl., Vol. 522, Pages 133-137, 1996.

20. I. Ali, O. M. Shafi, F. Khalid, and O. Makhdoomi, "Voice outcome after type-1 thyroplasty for unilateral vocal cord paralysis: our experience at tertiary care hospital,” Int. J. Otorhinolaryngol. Head Neck Surg., Vol. 6, Issue 8, 2020.

21. W. Wen, G. Sun, B. Sun, C. Liu, and M. Zhang, "Modified thyroplasty for unilateral vocal fold paralysis using an adjustable titanium implant," European Archives of Oto-Rhino-Laryngology. Vol. 272, Issue 3, Pages 517-522, 2015.

22. N. Maggon, A. Sethi, A. Mishra, and A. Mallick, "Type I thyroplasty for unilateral vocal fold palsy: Silastic or titanium implant?” J. Laryngol. Voice, Vol. 8, Issue 2, Pages 29-35, 2018.

23. H. Maeda, M. Tanabe, K. Mizoguchi, K. Yamamoto, and N. Isshiki, "Recent Surgical Technique for Vocal Cord Paralysis: Type I Thyroplasty with Titanium Plate,” Nihon Kikan Shokudoka Gakkai Kaiho, Vol. 62, Issue 2, Pages 206, 2011.

24. K. Yan and A. D. Friedman, "Surgical management of calcium hydroxyapatite in the superficial lamina propria of the vocal fold," Otolaryngol. Case Reports, Vol. 19, Pages 100-292, 2021.

25. J. T. Cohen and L. Benyamini, "Voice outcome after vocal fold injection augmentation with carboxymethyl cellulose versus calcium hydroxyapatite,” J. Laryngol. Otol., Vol 135, Issue 3, 2020.

26. J. R. Olmos-Zuñiga et al., "Comparison of lyophilized glutaraldehyde-preserved bovine pericardium with different vascular prostheses for use as vocal cords implants: Experimental study,” Biomed Res. Int., Vol. 2015, Pages 9, 2015.

27. W. Shi, G. Han, Y. Chang, H. Song, W. Hou, and Q. Chen, "Using Stretchable PPy@PVA Composites as a HighSensitivity Strain Sensor to Monitor Minute Motion," ACS Appl. Mater. Interfaces, Vol. 12, Issue 40, Pages 4537345382, 2020.

28. G. Illuminati, F. Schneider, A. Minni, F. G. Calio, G. Pizzardi, and J. B. Ricco, "Resection of recurrent neck cancer with carotid artery replacement," J. Vasc. Surg., Vol. 63, Issue 5, Pages 1272-1278, 2016.

29. O. Butskiy, B. Mistry, and N. K. Chadha, "Surgical interventions for pediatric unilateral vocal cord paralysis: A systematic review,"., Vol. 141, Issue 7, Pages 654-660, 2015.

30. W. C. Lin et al., "Radiofrequency ablation for treatment of thyroid follicular neoplasm with low SUV in PET/CT study,” Int. J. Hyperth., Vol. 38. Issue 1, Pages 963-969, 2021.

31. J. Xiao, M. Su, and D. Wang, "Endotracheal, Endobronchial, and Vocal Cords Metastases from Lung Cancer Detected by 18F-FDG PET/CT,” Clin. Nucl. Med., Vol. 46, Issue 3, Pages 225-226, 2021.

32. T. Uslar et al., "Papillary thyroid carcinoma presenting with pancreatic metastases. Report of one case," Rev. Med. Chil., Vol. 148, Issue 7, Pages 1025-1030, 2020.

33. E. Tseros, F. Riffat, C. E. Palme, H. G. Coleman, and N. P. Singh, 'Neville Wran's voice: How the premier's tefloncoated vocal cords came unstuck,” Med. J. Aust., Vol. 207, Issue 11, Pages 468-470, 2017.

34. R. B. Lewy and D. Millet, "Immediate local tissue reactions to teflon vocal cord implants," Laryngoscope, Vol. 88, Issue 8, Pages 1339-1342, 1978.

35. W. Prasong, P. Muanchan, A. Ishigami, S. Thumsorn, T. Kurose, and H. Ito, "Properties of 3D Printable Poly(lactic acid)/Poly(butylene adipate-co-terephthalate) Blends and Nano Talc Composites," J. Nanomater., Vol. 2020, Pages 16, 2020 . 
36. S. Zhang, Y. Liang, X. Qian, D. Hui, and K. Sheng, "Pyrolysis kinetics and mechanical properties of poly(lactic acid)/bamboo particle biocomposites: Effect of particle size distribution," Nanotechnol. Rev., Vol. 9, Issue 1, Pages 524$533,2020$.

37. L. Zichen and Y. Baoqing, "Development prospect and research value of biodegradable poly(Lactic acid) for bone repair," Chinese Journal of Tissue Engineering Research. Vol. 25, Issue 34, Pages 5552-5560, 2021.

38. L. Avérous, "Polylactic Acid : Synthesis, Properties and Applications," Synthesis (Stuttg)., Pages 433-450, 2008.

39. M. Todo and T. Takayama, "Fracture Mechanisms of Biodegradable PLA and PLA/PCL Blends," Biomater. - Phys. Chem., Pages 375-394, 2011.

40. D. Garlotta, “A Literature Review of Poly(Lactic Acid),” J. Polym. Environ., Vol. 9, Issue. 2, Pages 63-84, 2001.

41. G. P. Bernardes, N. da Rosa Luiz, R. M. C. Santana, and M. M. de Camargo Forte, "Influence of the morphology and viscoelasticity on the thermomechanical properties of poly(lactic acid)/thermoplastic polyurethane blends compatibilized with ethylene-ester copolymer,” J. Appl. Polym. Sci., Vol 137, Issue 2, 2020.

42. R. Donate, M. Monzón, M. E. Alemán-Domínguez, and Z. Ortega, "Enzymatic degradation study of PLA-based composite scaffolds,” Rev. Adv. Mater. Sci., Vol. 59, Issue 1, Pages 170-175, 2020.

43. Q. Wang et al., "Kinetic thermal behavior of nanocellulose filled polylactic acid filament for fused filament fabrication 3D printing,” J. Appl. Polym. Sci., Vol. 137, Issue 7, 2020.

44. S. Shen, K. Kopitzky, T. Sengül, K. Stephan, "Polylactide (PLA) and Its Blends with Poly(butylene succinate) (PBS): A Brief Review," Polymers, Vol. 11, Issue 7, Pages 1193, 2019.

45. J. A. Afonso, J. L. Alves, G. Caldas, B. P. Gouveia, L. Santana, and J. Belinha, "Influence of 3D printing process parameters on the mechanical properties and mass of PLA parts and predictive models," Rapid Prototyp. J., Vol. 27, Issue $3,2021$.

46. R. Revati, M. S. Abdul Majid, M. J. M. Ridzuan, M. Normahira, N. F. Mohd Nasir, and E. M. Cheng, "Biodegradation of PLA-Pennisetum purpureum based biocomposite scaffold,"Vol. 908, Issue 1, 2017.

47. E. H. Baran and H. Yildirim Erbil, "Surface modification of 3d printed pla objects by fused deposition modeling: A review," Colloids and Interfaces. Vol. 3, Issue 2, page 43, 2019.

48. H. S. Barud et al., "Polylactic acid scaffolds obtained by 3D printing and modified by oxygen plasma," Rev. Bras. Multidiscip., Vol. 23, Pages 97-106, 2020.

49. A. Pentek et al., "The effect of printing parameters on electrical conductivity and mechanical properties of PLA and ABS based carbon composites in additive manufacturing of upper limb prosthetics," Crystals, Vol. 10, Issue 5, page 398, 2020.

50. Triwiyanto, T. Hamzah, S. Luthfiyah, I. P. A. Pawana, and B. Utomo, "A low cost and open-source anthropomorphic prosthetics hand for transradial amputee,", Vol. 2202, Issue 1, 2019.

51. D. C. Hall, P. Palmer, H. F. Ji, G. D. Ehrlich, and J. E. Król, "Bacterial Biofilm Growth on 3D-Printed Materials," Front. Microbiol., Vol. 12, Pages 1-13, 2021.

52. R. Hashemi Sanatgar, "FDM 3D printing of conductive polymer nanocomposites: A novel process for functional and smart textiles," Skr. från Högskolan i Borås NV, Vol. 97, Pages 136 - 97, 2019.

53. Y. Kumai, "Pathophysiology of fibrosis in the vocal fold: Current research, future treatment strategies, and obstacles to restoring vocal fold pliability,” International Journal of Molecular Sciences. Vol. 20, Issue 10, page 2551, 2019.

54. M. Devos, P. Schultz, F. Guilleré, and C. Debry, "Thyroplasty for unilateral vocal fold paralysis using an adjustable implant in porous titanium,” Eur. Ann. Otorhinolaryngol. Head Neck Dis., Vol. 127, Issue. 6, Pages 204-212, 2010. 
55. J. J. Daniero, C. G. Garrett, and D. O. Francis, "Framework Surgery for Treatment of Unilateral Vocal Fold Paralysis," Current Otorhinolaryngology Reports. Vol. 2, Issue 2, Pages 119-130, 2014.

56. C. M. Dean, C. Ahmarani, M. Bettez, and R. J. Heuer, “The adjustable laryngeal implant,” J. Voice, Vol. 15, Issue 1, Pages 141-150, 2001.

57. G. Friedrich, "Titanium vocal fold medializing implant: Introducing a novel implant system for external vocal fold medialization,” Ann. Otol. Rhinol. Laryngol., Vol. 108, Issue. 1, Pages 79-86, 1999.

58. M. S. Montgomery WW, "Montgomery Thyroplasty Implant System,” Ann Otol Rhinol Laryngol, Vol. 106, page $170,1997$.

59. E. J. Muse AM, Montgomery WW, Hilman RE, Varvares MA, Bunting G, Dyle P, "Montgomery throplasty implant for vocal fold immobility; phonatory outcomes," Ann Otol Rhinol Laryngol, Vol. 109, Pages. 393-400, 2000.

60. C. Storck et al., "Hydroxyapatite versus titanium implant: Comparison of the functional outcome after vocal fold medialization in unilateral recurrent nerve paralysis," Head Neck, Vol 32, Issue 12, Pages 1605-1612, 2010.

61. C. Storck, M. Brockmann, E. Schnellmann, S. J. Stoeckli, and S. Schmid, "Functional outcome of vocal fold medialization thyroplasty with a hydroxyapatite implant," Laryngoscope, Vol. 117, Issue 6, Pages 1118-1122, 2007.

62. T. K. Meyer and A. Blitzer, "Medialization thyroplasty using the vocom vocal cord medialization system," in Vocal Fold Paralysis, Pages 159-163, 2006.

63. P. S. Mallur and C. A. Rosen, "Vocal fold injection: Review of indications, techniques, and materials for augmentation," Clinical and Experimental Otorhinolaryngology. Vol. 3, Issue 4, Pages 177-182, 2010.

64. C. W. Cummings, L. L. Purcell, and P. W. Flint, "Hydroxylapatite laryngeal implants for medialization: Preliminary report," Ann. Otol. Rhinol. Laryngol., Vol. 102, Issue 11, $\quad$ Pages 843-851, 1993.

65. M. S. Tsai, M. Y. Yang, G. H. Chang, Y. Te Tsai, M. H. Lin, and C. M. Hsu, "Autologous thyroid cartilage graft implantation in medialization laryngoplasty: A modified approach for treating unilateral vocal fold paralysis," Sci. Rep., Vol. 7, Pages 4790, 2017.

66. W. W. Montgomery et al., "Montgomery® thyroplasty implant for vocal fold immobility: Phonatory outcomes,” Ann. Otol. Rhinol. Laryngol., Vol. 109, Issue 4, Pages 393-400, 2000.

67. W. W. Montgomery and S. K. Montgomery, "Montgomery® thyroplasty implant system," Annals of Otology, Rhinology and Laryngology. Vol. 170, Pages 1-16, 1997.

68. N. Van Ardenne, J. Vanderwegen, G. Van Nuffelen, M. De Bodt, and P. Van De Heyning, "Medialization thyroplasty: Vocal outcome of silicone and titanium implant," Eur. Arch. Oto-Rhino-Laryngology, Vol. 268, Issue 1, Pages 101-107, 2011. 